\title{
Islamic Mystical Theology and Neoplatonism: The Case of Jalal al Din Rumi
}

\author{
Saeed Zarrabi-Zadeh \\ University of Erfurt, Germany
}

\begin{abstract}
One major Hellenistic tradition that has enjoyed considerable influence over Islamic philosophy and mysticism is Neoplatonism. Through the Baghdad-based Greco-Arabic translation movement of the mid-eighth to tenth century, significant Neoplatonic works were translated into Arabic, though usually misascribed to Aristotle, the First Teacher (al-mu allim al-awwal) of Islamic philosophy. While the theological discourses of early Muslim mystics (Sufis) such as Dhu al-Nun al-Mișri (d. ca. 860) and Sahl al-Tustari (d. ca. 896) indicate only potential Neoplatonic influence, such impact became more visible after the twelfth century. Specifically, the Andalusian Sufi Ibn Arabi (d. 1240) and his philosophically-minded disciples developed the doctrine of the "unity of being" (wahdat al-wujud) based on the theory of "emanation," a cornerstone of Neoplatonic metaphysics. Ibn 'Arabi's authoritative stance as the Greatest Master (al-shaykh al-akbar) of Sufism assured the presence of Neoplatonic elements in later Sufi theology. This paper argues that despite such strong intellectual influence, Muslim mystics varied in their reception of Neoplatonic principles. While some Sufis incorporated Neoplatonism into their theology and some others distanced themselves from this Hellenistic tradition, a third group tried to develop a hybrid mystical theology that, though including Neoplatonic elements, were more in accordance with the image of God as presented in the Qur'an. This paper especially analyzes the mysticism of a notable representative of the latter group, Jalal al-Din Rumi (d. 1273), whose thought shares several commonalities with Neoplatonism yet differs from it on three fundamental issues, namely God's nature, the Divine will, and the successive stages of emanation.
\end{abstract}

Keywords: Islamic mysticism, Persian Sufism, comparative religions, emanation, cultural transfer 